\title{
A Study of the Instructional Media Used by the Teachers in Teaching English
}

\author{
Ni Putu Rika Ristika1 ${ }^{*}$, Ni Made Ratminingsih², N. P. A Pratiwi ${ }^{3}$ \\ ${ }^{123}$ English Language Education Ganesha University of EducationSingaraja,Indonesia
}

\begin{abstract}
This study was a descriptive qualitative which intended to investigate the types of instructional media used and the implementation done by the English teachers. The instructional media used to become the best solution to overcome the learning problems faced by the teachers. The subjects of this study were 5 English teachers at SMPN 2 Melaya. The data were collected through observation during the teaching and learning process and interviews with the teachers. The data analyzed descriptively. From the overall findings, the English teachers used eight types of instructional media, such as; real objects or models, slides, pictures, video, web, audio, books, and the boards. The teachers had different ways to implement them, such as they used LCD Projector and speakers as the tools to show the material and the school environment as the realia. The lack of facilities became the main problem in implementing them. Moreover, the teachers tend to use the same instructional media for the other topic since they do not have enough time to prepare.
\end{abstract}

\section{Keywords:}

instructional media, teaching English, the implementation 


\section{INTRODUCTION}

English has been considered as a foreign language which difficult to be taught in Indonesia. According to Derakshan (2015), learning English as a foreign or second language in Indonesia is difficult because the learners cannot use English in everyday life, and they learn the language based on the textbooks, not in a real environment. Therefore, the issue is how the teacher can manage the teaching and learning process while dealing with the phenomenon. Rokhayani and Utari (2014) explained that teachersare the main key in the classroom during the teaching and learning process.

In Indonesia, English has been taught since Elementary School, but the teacher still faced some problems in delivering the material to the students. Maili and Hestiningsih (2016) stated that two factors affect the English learning problem, such as the teacher does not use an interesting method to catch the students' attention, and the school does not support the teaching media that will be used by the teacher.

The teacher can use the innovation of teaching media nowadays to overcome these problems. According to Ratminingsih (2016), good media for teaching can help the teacher to transfer the material to the students, getting their attention, create an enjoyable learning process, and motivate the students. It means that the instructional media for teaching used as a component to achieve the learning goals. Similarly, Maili and Hestiningsih (2016) stated that the teacher should develop the methods and teaching media before teaching English. The teachers are suggested to develop the teaching process by integrating the technology to motivate the learners in learning English (Astrini et al.,2020).

One of the roles of the teachers is teachers should have an effective strategy to teach English as a foreign language in Indonesia. Gushendra (2017) explained that teachers should have several instructional media to make their students motivated to learn English. The students need a modification of teaching, which can involve them in English. Moreover, Dewi et al. (2020) found that combining the material with any devices, such as mobile devices, can be an alternative strategy to give students' experiences in learning English. According to Ali (2009), there are two aspects to support successful learning, such as the teaching material and the instructional media. The teaching materials depend on the syllabus of the course in each school. Besides, the instructional media for the teaching and learning process depend on the teachers' knowledge of implementing it.

The use of instructional media in the teaching and learning process is essential. According to Adegbia and Fakomogbon (2012), the instructional media are the human and non-human devices, material, or methodologies used by the teachers to overcome all learning problems. It means that the instructional media is the key to transfer the knowledge from the teacher to the students effectively. Mateer, et al. (2018) also stated that the use of media in teaching English would help students easier to relate the concepts with the context.

Based on the preliminary observation done, it was found that the teachers in SMPN 2 Melaya used instructional media for teaching English. This school is located in a small village, but the teachers have many ways to build the students' understanding. One of them is by using the kinds of instructional media. It showed the teacher's knowledge of instructional media in this school is not less compared to the school located in the city. Thus, the current study has conducted another study in the form of a descriptive qualitative method. This study aimed to describe the teachers' instructional media and its implementation in teaching English in SMPN 2 Melaya, Jembrana Regency.

\section{METHOD}

This study was utilized descriptive qualitative research, which focused on observing the teachers' instructional media used and its implementation in teaching English at SMPN 2 Melaya. The subjects of this study were the English teachers and students at SMPN 2 Melaya. The data were obtained from the observation during the teaching and learning process, interview, and questionnaire. It was conducted the observation toward the activities among the teachers and students in the classroom. Besides, the observation of the utilization of instructional media was noted on the observation sheet. In the interview, the teachers were given nine questions, and the results were used to strengthen the data obtained from the observation. The interview guidelines were used to keep the focus of the data needed to be analyzed. The students were given questionnaires to find out their responses toward the instructional media used.

The data analysis technique used the Interactive Model Analysis from Miles and Huberman (1994). The interactive model analysis is a technique of analysis that consists of four components, such as; data collection, data reduction, data display, and conclusion or verifying. In collecting the data of the interview, it used the audio recording to record the interview done by 5 participants. After finishing the process of data collection, the second step is moving into the data reduction. Data reduction is the process of selecting and focusing the data according to what is the essence of the interview. After finishing the 
process of data reduction, the next step is conducting a data display. Data display is the process of arrangement data, which allows the study to take action based on the data. The last step is the conclusion. The data that has been gathered and finish the process of reduction and displaying then concluded clearly.

\section{FINDING AND DISCUSSION}

\section{A. Findings}

Based on the observation done from January, 17th 2020 to February, 11th 2020, the researcher had found eight instructional media that commonly used by the English teachers' at SMPN 2 Melaya. There were real objects or models, slides, pictures, video, web, audio, books, and boards. Besides, the teachers also used the boards and books that the school has to give more precise explanations of the material and used when the teachers did not have another instructional media to transfer the material.

The result data of the interview with the teachers showed that the most used media in 1 semester were books and pictures. The minimum facility in this school caused it. The teachers needed to book Computer Lab before using it to show video or using the LCD Projector. Moreover, in using the real object that available in the school, the teachers needed more preparation and attention to the students to make them focus on the teaching and learning process even though they were hanging around the school.

The teachers did several steps to implement both of the instructional media used. The first was teaching Simple Present Tense using PowerPoint. In this case, the teacher used LCD Projector as the tool to show the material. After explaining and giving an example, the teacher asked the students to make sentences in the form of positive, negative, and interrogative then discussed it together in the classroom. The second was teaching Narrative text using video. For this material, the teacher also needed help from LCD Projector to show the video. Besides, it also used speakers for listening to the story and music. After watching and discussing the information of the story, the teacher asked the students to create a group consist of four or five students and find the other related story as the assignment.

The next was teaching Asking and Giving Information about the characteristic of people, animals, and things. It was found two different ways to teach this material. The first was using the real things and objects found at school as the instructional media. After discussing the adjectives that might be used, the teacher asked the students to find out the animals, people, and things around the school. The students could describe and present the result in front of the class. It was a little bit different from the second English teacher who taught the same topic. The instructional media used by the second teacher was pictures that showed using LCD Projector in Computer Lab. In implementing this kind of instructional media, the teacher show and discuss the people, animal, and things in the pictures showed.

The researcher also observed the teacher who taught Present Continuous Tense using Mr.Bean's video. The teacher and the students were watching the video and discussing the daily activity there together. The next observation was teaching $\mathrm{W}-\mathrm{H}$ question using scripted song. The teacher gave the students W-H question in English and Bahasa Indonesia in a form of song. The last observation was teaching comparison using the website of https://www.intraxenglish.com/degrees-of-comparison/. After showing the material, the teacher asked the students to create others' comparisons using adjectives that they already found and discussed it together.

Besides did the observation and interview, further data also gained through a questionnaire given to $30 \%$ of the total students in classes that already observed. The total number of students was 296. Thus, the questionnaires were shared with 89 students. The results of the questionnaire showed that the students' responses to the instructional media used by the English teachers at SMPN 2 Melaya were diverse. The students' responses in realia were $77 \%$ often used, pictures $76 \%$ often used, slides $86 \%$ often used, songs $60 \%$ often used, web $83 \%$ often used, and books $54 \%$ frequently used. Thus, it can be concluded that these kinds of instructional media for teaching English at SMPN 2 Melaya already implemented. In addition, it was found that the teachers used games, dictionary, and giving practice in teaching English. Besides, the students' responses toward the teachers' who used instructional media for teaching English were very positive. Most of the respondents said it is interesting to learn English using instructional media. They were easy to understand, remember the topic, and enjoy the teaching and learning process.

\section{B. Discussion}

In this research, the researcher adapted Harmer (2007), Mahajan (2012), and Arsyad's (2009) theories to identify the types of instructional media used by the English teacher during the teaching and learning process at SMPN 2 Melaya. According to Harmer (2007), Mahajan (2012), and Arsyad (2009), there are nine types of instructional media, such as real objects or models, printed text, printed visual, display boards, interactive whiteboards or slides, audio, video or film, television, and the computer 
software or web. Besides, the English teachers' at SMPN 2 Melaya used eight types of instructional media classified by Harmer (2007), Mahajan (2012), and Arsyad's (2009) theories. There were real objects or models, slides, pictures, video, web, audio, books, and boards.

These kinds of instructional media for teaching English also found in some related studies. The first study was conducted by Rahmi (2014) in implementing the media in English language teaching. It found that there were ten types of instructional media used, such as; audio, book, magazine, newspaper, picture flashcard, poster, realia, puzzle, and blackboard. Another study was conducted by Aini (2013) in investigating the instructional media for teaching English to young learners. The result of the study found that there were four types of instructional media used, such as; boards, realia, pictures, and books.

In comparison with the study conducted by Rahmi (2014) and Aini (2013), this study found that the types of instructional media used by the English teachers at SMPN 2 Melaya were realia, books, boards, pictures, PowerPoint, voice, video, and the web. Based on those types, it can be concluded that this study had found two different instructional media for teaching English, that was the video and web. Besides, there also four similar types of instructional media commonly used, such asrealia, books, pictures, and boards.

The books and printed pictures became the most instructional media used for teaching English in SMPN 2 Melaya. Besides, based on the result of data found that the use of web as the instructional media for teaching English became the most rarely. Moreover, there was only one teacher who used the web. Nowadays, media (the internet) become an essential thing in all fields. According to Lim (2019), there are synchronous learning and asynchronous learning. The synchronous learning means the teaching and learning process occurs in a real-time or scheduled using web. It is just like the teaching and learning process in the traditional classroom. The teacher and the students can interact spontaneously. In reverse, the asynchronous means the use of electronic technology as the media for teaching, which can be accessed anytime and anywhere. In this type, the students freely learn when they can, but they cannot get immediate feedback.

An ability to organize a computer is needed. The use of computer and internet in education fields gives training and develop the students' skills (Ogbonna et al. 2019). Their study also found that the students' cognitive achievements were improved in asynchronous learning treatment. On the other side, the students who were treated in synchronous learning showed better skills acquisition. It means that both the synchronous and asynchronous e-learning modes give advantages to the students. However, the use of web as the instructional media for teaching in the study was found as the most rarely used, but the truth is it beneficial and helpful in today's phenomena.

Based on the teachers' perception training program conducted by Ratminingsih et al. (2018), found that the teachers gave positive perception towards this teacher training program. The program provides teacher training and mentoring of the use of ICT in the games as one of the instructional media for teaching English. It includes the step of operating the media, the way to create lesson plans considering the media, and using the media in teaching. After joining this program, the teachers will be able to increase their knowledge of using and innovating technology as the teaching media. They believe that it can pay the students' attention, motivate, and also involve the students in the teaching and learning process. In this case, the use of technology to support the teaching media helps the teacher to update their teaching. Moreover, the students' responses to media-based technology also prove that they are very enthusiastic about it. Thus, it means that the teachers in SMPN 2 Melaya needed to improve the teaching media, especially in using technology, in this case, computer or the web.

The interview data showed that the teachers felt the use of instructional media during the teaching and learning process for each material was helpful. They were easily prepared for the material before the class was started. It also helped them to deliver the material to the students. Therefore, it increased their readiness and confidence in teaching. In addition, the teachers also felt the students' motivations were increased when they used the instructional media. It was shown by the improvement of the students' vocabulary.

The results of the interview were in line with other previous studies. One of them is a study conducted by Fatimah (2017) on the students' and teachers' perceptions of using technology as the teaching media in the classroom. This study found that both of the teachers and the students were interested in using those tools for teaching. Another related study was conducted by Mohan (2013) in using instructional media for effective language teaching. The result of this study showed that the use of instructional media in the teaching and learning process was appealed to the senses, reinforces the memory of the students, and makes the lesson more interesting. Besides, it made the teaching and learning process more meaningful to achieve the learning goals. Similarly, Rokhayani and Utari (2014) also did a related study in using comic strips as the teaching media. This study found that the students' 
achievements in English courses were improved, and the teacher felt easier to deliver teaching materials using this instructional media.

The functions of using instructional media in the teaching and learning process, which were investigated in this study are in line with the result found by Fatimah (2017), Mohan (2013), and Rokhayani and Utari (2014). Those studies were compared to gain the data that support this study. Furthermore, it was found that the use of instructional media gave some advantages, such as the teachers have enough time to prepare the material that would be taught.It increased their readiness and confidence in teaching. It helped them to deliver the material easily to the students, and also it catched students attention, motivation, and achievement. Besides, Ratminingsih et al. (2018) also found that instructional media becomesa way to achieve a successful teaching-learning process. It gives an important role in managing the classroom as well as transferring the material better.

Based on the data of the interview, it was found the problem faced by the English teachers at SMPN 2 Melaya in implementing the instructional media to the teaching and learning process. It was the availability of the tools to support instructional media. In this case, the tools mean the LCD Projector, Speaker, and Computer Lab available in the school. The limitation of the facilities to support the instructional media in schools in Indonesia also found in several related studies. The first study conducted by Songbatumis (2017) in challenges in teaching English faced by the English teachers. The result of this study showed that some factors caused the problem. One of them was the facilities' issues, including inadequate resources and facilities, and time constraint.

The second study conducted by Hestiningsih and Maili (2016)found that the school did not support the English lesson; for example, lack of facilities and the English teachers were never given training. The third study conducted by Aini (2013) also found the problem in implementing the instructional media into the teaching and learning process was the technical problem, including the dysfunction of high-tech instructional media used. Therefore, it can be concluded that the main problem in implementing the instructional media in some schools in Indonesia is the limitation of facilities to support it, which is similar to the result of this study.

\section{CONCLUSION AND SUGGESTION}

Based on the findings and discussion, there were two conclusions as the result. (1) The English teachers used several kinds of instructional media to teach English in SMPN 2 Melaya. There are real object, pictures, power point, voice (song), and the web. Moreover, the teachers also used the boards and books for clearer explanation. Based on the interview, the teachers will used the books that they got from the school if they could not prepare any other in instructional media before the class is started. (2) Based on the observation done, the teachers have different ways to implement the instructional media to teach English. The first was teaching simple present tense using power point. The teacher also used LCD Projector as the tool to show it. The second was teaching narrative text using video of "Snow White", besides the teacher used LCD Projector and speakers as the tools to show it and increase the students listening skill. The third was teaching asking and giving information about the characteristics of people, animal, and things. In this topic, there were 2 teachers who used different instructional media to explain the material. The first teacher was used real things and objects that the students found at the school. The other one was used picture and LCD Projector as the tool to show the people, animal, and things that will be explained.

The fourth observation was teaching present continuous tense using video of Mr. Bean's daily activities. It also used the LCD Projector and speakers as the tools to show it to the students. The fifth was teaching $\mathrm{W}$-H question using scripted song as the instructional media. Here the teacher was created a scripted song contains $\mathrm{W}-\mathrm{H}$ question and its meaning in Bahasa Indonesia. The last was teaching comparison using the web. It used computers and LCD Projector as the tools to help the teacher explain the material to the students. The website used was https://www.intraxenglish.com/degrees-ofcomparison/.

As the result of the interview data, the teachers used boards and books from school to develop the students' understanding by reading and answering the assignments there. They also used books as the alternative if they could not prepare the other instructional media to explain the material. Besides, the results of the questionnaire which used to find out the further data of kinds of instructional media used by the teachers in teaching English at SMPN 2 Melaya prove that the teaches here used realia, pictures, slides, song, web, and books as the instructional media.

The implementation of these instructional media needs a help by the school's tools. However, based on the observation and interview done, SMPN 2 Melaya only has 2 LCD Projector and 1 Computer Lab. It 
became a problem in implementing the instructional media to teach English. In fact, the teacher should alternately to use it, or they have to book it first. The teachers also commonly feel do not have enough time to prepare the other kinds of instructional media. Therefore, they tend to use the same instructional media on the other topics.

After conducting a study at SMPN 2 Melaya, several suggestions can be put forward as follows; (1) Instructional media can help the teacher to explain the material and built the students' understanding easily. It has been proved by some related study. Therefore, it is really recommended for the English teachers to implement the instructional into the teaching and learning process. There are many types of instructional media that can be prepared and implemented by the teacher, so the students will not get bored during the teaching and learning process at school. The use of instructional media can accommodate the curriculum's need as well. However, the teachers need to improve the implementation to be more innovative as the instructional media used. (2) It is suggested for the other researchers to conduct other related studies focusing on the use of instructional media in teaching English for junior high school since the result of this current study is applicable in limited number of sample. Therefore, the other studies will be able to strengthen the types and its implementation of the instructional media for teaching English. Besides, the time management is really important to manage all the preparation in conducting a research.

\section{REFERENCE}

Adegbia, M. V. \& Fakomogbon, M. A. (2012). Instructional media in teaching and learning: A Nigerian Perspective. Global Media Journal, 6(2), 216-230.

Aini, W. N. (2013). Instructional media in teaching English to young learners: A case study in elementary school in Kuningan. Journal of English and Education, 1(1), 196-205.

Ali, M. (2009). Pengembangan media pembelaaran interaktif mata kuliah medan elektromagnetik. Jurnal Pendidikan teknik Elektro FT UNY, 5(1).

Astrini, N. F, Ratminingsih, N. M, Utami I. G. A. L. P. (2020). The model of strategies employed by English teachers in teaching writing skill in National Plus Schools. Journal of Education Research and Evaluation, 4(1), 59-62.

Arsyad, A. 2009. Media pembelajaran. Jakarta: Rajawali Pers.

Arsyad, A. 2013. Media pembelajaran. Jakarta: Rajawali Pers.

Brown, H. D (2001). Teaching by principles: An Interactive Approach to Language Pedagogy. Englewood Cliffs: Prentice Hall.

Cameron, L. (2001). Teaching languages to young learners. Cambridge: Cambridge University Press.

Chamunorwa, J.(2010). Discussion Method of Teaching and Learning. Retrieved from http://zvavanhuchopper.blogspot.com/2010/10/discussion-method-of-teaching-and.html

Denzin, N. K., \& Lincoln, Y. S .(1994). Introduction: Entering the field of qualitative study. Thousand Oaks, Sage Publications.

Derakhshan, A. (2015). The difficulties of teaching English language: the relationship between research and teaching. International Journal of Linguistics, 7(1), 102-110.

Dewi, P. A. K, Ratminingsih, N. M, Santosa, M, H. (2020). Mobile-assisted task-based language learning, writing competency, and motivation. Jurnal Pendidikan Indonesia, 9(1), 119-130.

Fatimah, A. S. (2017). Teaching in 21st century: students-teachers' perception of technology use in the classroom. Journal of Linguistic and English Teaching, 2(2).

Gushendra, R. (2017). An experimental study: improving students' vocabulary mastery by using English song. Indonesian Journal of Integrated English Language Teaching, 3(1), 53-63. 
Harmer, J. (2007). The Practice of English Language Teaching. New York: Longman Inc.

Heinich, R. Molenda, M. Russell, J.D, \& Scnaldino, S.E. (1996). Intructional and the New Tecnologies of Instruction. New York: Macmillan.

Hestiningsih, W. \& Maili, S. N. Masalah-masalah pembelajaran Bahasa Inggris pada Sekolah dasar. Media Penelitian Pendidikan, 11(2), 54-62.

Lee. A. Y. (2016). Media education in the School 2.0 era: Teaching media literacy through laptop computers and iPads. Journal of Global Media and China, 1(4), 435-449.

Lim. F. P. (2019). An analysis of synchronous and asynchronous communication tools in e-learning. Advanced Science and Technology Letters, 143(46), 230-234.

Mahajan, G. (2012). Multimedia in Teacher Education: Perceptions and Uses. Journal of Education and Practice, 3(1), 5-12.

Mateer, G. D., Ghent, L. S., Porter, T., \& Purdom, R. (2018). Using Media to Enhance Teaching and Learning. Action the SERC Portal for Educators: https://serc.carleton.edu/sp/library/media/index.html

Maili, S., N. \& Hestiningsih, W. (2016). Masalah-masalah pembelajaran Bahasa Inggris pada Sekolah Dasar. Media Penelitian Pendidikan, 11(2), 54-62.

Miles, M. B., \& Huberman, A. M. (1994). Qualitative data analysis (2nd ed). London: New Delhi

Mohan,. S. (2013). Instructional media for effective language teaching. International Journal of Humanities, Arts, Medicine and Science. 1(3), 81-84.

Ogbonna, C. G., Ibzeim, N. E., Obi, C. A. (2019). Synchronous versus asynchronous e-learning in teaching word processing experimental approach. South African Journal of Education, 39(2), 1-15.

Onyia \& Mary, N. (2013). Instructional materials and design: issues and challenges. Academic Journal of Interdisciplinary Studies, 2(6), 153-158.

Rahmi, R. (2014). The implementation of media in English language teaching. STKIP Bina Bangsa Getsempena Banda Aceh, 5(1), 1-16.

Ratminingsih. N. M. (2016). Efektifitas media audio pembelajaran Bahasa berbasis lagu kreasi di kelas lima Sekolah Dasar. Jurnal Pendidikan Indonesia, 5(1), 27-38.

Ratminingsih, N. M., \& Budasi, I. G. (2012). Pelatihan pemanfaatan lagu-lagu kreasi khusus (scripted songs) dalam pembelajaran bahasa Inggris berbasis tema di sekolah dasar di Kecamatan Sukasada Kabupaten Buleleng. Laporan P2M. Universitas Pendidikan Ganesha.

Ratminingsih, N. M, Mahadewi, L. P. P, Divayana, D. G. H. (2018). ICT-Based interactive game in TEYL: teachers' perception, students' motivation, and achievement. International Journal of Emerging Technologies in Learning, 13(9), 190-203.

Reiser, R. A., \& Dick, W. (1995). Instructional Planning: A guide for teachers (2nd ed).

Rodgers, D. L. (2005). The effect of instructional media on learner motivation. International Journal of Instructional Media, 32(4), 333-342.

Rokhayani, A. \& Utari, A. R. P (2014). The use of comic strips as an English teaching media for Junior High School students. Language Circle Journal of Language and Literature, 8(2), 143-149.

Sadiman, A., Sudjarwo, S., \& Radikun. (1986). Media pendidikan: pengertian, pengembangan, dan pemanfaatannya (6th ed). Jakarta: CV Rajawali. 
Sukmahidayanti, T. (2015). The utilization of instructional media in teaching English to young learners. Journal of English and Education, 3(2), 90-100.

Songbatumis, A. M. (2017). Challenges in teaching Enlish face by English teachers at MTsN Taliwang, Indonesia. Journal of foreign language teaching and learning, 2(2), 54-67.

Tamrin, M., Azkiya, Hidayati. \& Sari, S. G. (2017). Problems faced by the teacher in maximizing the use of learning media in Padang. Al-Ta'lim Journal, 24(1), 60-66.

Yassaei, S. (2012). Using original video and sound effect to teach English. English Teaching Forum, 1, 1216. 